\title{
UPAYA PEMBINAAN TERTIB ADMINISTRASI DESA OLEH DINAS \\ PEMBERDAYAAN MASYARAKAT DAN PEMERINTAHAN DESA \\ KABUPATEN SINTANG
}

\author{
Antonius Erwandi \\ Fakultas Ilmu Sosial Dan Ilmu Politik Universitas Kapuas Sintang \\ Jalan Oevang Oeray 92 Sintang \\ Email : erwandi.unka@gmail.com
}

\section{Abstract}

The orderly administration of the village becomes the authority of the Sintang District Village Empowerment and Village Administration Office which aims to achieve good and effective village government performance in its administration system. The research method used is a qualitative descriptive approach, data analysis techniques are qualitative, the tools used are Observation Guide, Interview Guidelines and documentation. The subjects of the study were 5 people, namely the Head of the Sintang District Village Community Empowerment and Village Empowerment Office, Sintang District Village Empowerment and Community Empowerment Office Secretary, Sintang District Village Empowerment and Community Empowerment Office Administration Staff, the Administrative Staff of the Sintang District Village Community Empowerment and Government Administration Office. Village Chief in Sintang Regency 2 people. Implementation of Administrative Guidance is carried out on an ongoing basis through technical guidance, work meetings and direct visits to villages, Coordination in the Implementation of Administrative Coaching is carried out internally in the Office of Community Empowerment and Village Government by the Head of the Institutional Section because of the interrelated coaching from various aspects such as finance and also administrative order, Supervision of the implementation of Administrative Development together according to the authority of the Office of Community Empowerment and Village Government

Keywords: Efforts, Guidance, Orderly Administration.
Abstrak
Tertib administrasi desa menjadi kewenangan pada Dinas Pemberdayaan dan Pemerintahan Desa Kabupaten Sintang yang bertujuan untuk mencapai kinerja pemerintah desa yangbaikdanefektifdalamsistemadministrasinya.
Metode penelitian yang digunakan yaitu pendekatan deskriptip kualitatif, teknik analisis data adalah kualitatif, alat yang digunakan yaitu Panduan Observasi, Pedoman wawancara dan 
dokumentasi. Subjek penelitian sebanyak 5 orang

yaitu Kepala Dinas Pemberdayaan Masyarakat

Dan Pemerintahan Desa Kabupaten Sintang,

Sekretaris Dinas Pemberdayaan Masyarakat Dan

Pemerintahan Desa Kabupaten Sintang, Kepala

Bidang Kelembagaan Dinas Pemberdayaan

Masyarakat Dan Pemerintahan Desa Kabupaten

Sintang, Staf Administrasi Dinas Pemberdayaan

Masyarakat Dan Pemerintahan Desa Kabupaten

Sintang. Kepala Desa di Kabupaten Sintang 2 orang.

Pelaksanaan Pembinaan Administrasi dilakukan secara berkelanjutan melalui bimbingan teknis, rapat kerja dan peninjauan

langsung kedesa-desa, Koordinasi Dalam Pelaksanaan Pembinaan Administrasi dilakukan di internal Dinas Pemberdayaan Masyrakat dan Pemerintahan Desa oleh Kepala Seksi Kelembagaan kareana karena keterkaitan pembinaan dari berbagai aspek seperti keuangan dan juga tertib administrasinya, Pengawasan pelaksanaan Pembinaan Administrasi secara bersama-sama menurut kewenangan pada Dinas Pemberdayaan Masyarakat dan Pemerintahan Desa

Kata Kunci : Upaya, Pembinaan, Tertib Administrasi.

\section{Pendahuluan}

Administrasi desa merupakan seluruh kegiatan pemerintah desa yang berkaitan dengan penyelenggaraan tata pemerintahan, dalam konteks administrasi desa yang lebih sederhana yaitu bentuk-bentuk pelaporan dan arsip-arsip desa yang menjadi tanggungjawab pemerintah desa, selain itu administrasi desa juga sebagai bukti dari tertib penggunaan anggaran-anggran dan bantuan desa yang direalisasikan sesuai dengan rencana kerja anggaran dan disertai dengan bukti administrasi penggunaannya.

Pentingnya pembinaan pada seluruh pemerintahan desa dalam menjalankan pemerintahan pada dasarnya sebagai suatu proses yang berkelanjutan menuju pada suatu tatanan pelaksanaan administrasi yang lebih baik. Menurut Manulang (2009 : 11) Dalam istilah Manajemen pembinaan dapat di samakan dengan Comanding yaitu fungsi manajemen yang berhubungan dengan bimbingan,saran,perintah dalam melaksanakan tugas masing-masing agar tugas dapat tertuju pada tujaun semula. Berdasarkan pada pendapat tersebut dapat diartikan bahwa pembinaan pada pemerintah desa khususnya dalam konteks administrasi agar mengarah pada konsep good governance di desa dimana pemerintahan yang efektif dan kuat merupakan ujung tombak dari keberhasilan pembangunan.

Pembinaan dalam hal ini untuk melihat secara satu persatu desa atau pemerintah desa yang bermasalah akan tetapi meninjau dari sudut pandang pembinaan yang dilakukan dalam upaya mengarahkan setiap kegiatan 
penyelenggaraan pemerintahan desa untuk mengacu pada suatu ketetapan yang standar. Sehingga seluruh desa di bimbing untuk tetap bekerja sesuai dengan peraturan tersebut, Dengan kata lain peran Dinas Pemberdayaan Masyarakat dan Pemerintahan Desa lebih pada upaya prefentif pada pemerintah desa dalam berbagai aspek sehingga pemerintah desa tidak melakukan kesalah dalam administrasinya, sebaliknya jika terdapat kekeliruan dalam adminisrasi masih diberikan waktu untuk memperbaiki.

\section{Pembahasan}

\section{A. Pelaksanaan Program Pembinaan}

\section{Administrasi Pemerintahan}

Menurut Gie $(2007$ : 12) Administrasi
perDinasan dapat didefenisikan sebagai
perencanaan, pengendalian, dan pengorganisasian
pekerjaan perDinasan, serta penggerakkan mereka
yang melaksanakannya agar mencapai tujuan-
tujuan yang telah ditentukan lebih dahulu. Menurut
Affidudin (2010:44) yaitu bagian dari proses
manajemen yang berhubungan dengan institusi dan
pelaksanaan prosedur yang digunakan untuk
menentukan dan mengkomunikasikan program dan
perkembangan kegiatan diatur dan dicek
berdasarkan target dan rencana. Sehingga dapat
disimpulkan bahwa manajemen perDinasan
merupakan rangkaian aktivitas merencanakan,
mengorganisasikan, mengarahkan, mengawasi dan
mengendalikan hingga menyelenggarakan

secara tertib pekerjaan administrasi perDinasan untuk menunjang pencapaian tujuan organisasi.

Menurut Gie (2007 :16) ruang lingkup tugas administrasi perDinasan dapat dikatakan tugas pelayanan disekitar keteranganketerangan yang berwujud 6 (enam) pola perbuatan, yakni :

a. Menghimpun yaitu : kegiatan-kegiatan mencari dan mengusahakan tersedianya segala keterangan yang tadinya belum ada atau berserakan dimana-mana sehingga siap untuk dipergunakan bilamana diperlukan.

b. Mencatat yaitu : kegiatan yang mebubuhkan dengan berbagai peralatan tulis keteranganketerangan yang diperlukan sehingga berwujud tulisan yang dapat dibaca, dikirim dan disimpan. Dalam perkembangan teknologi modern sekarang ini termasuk pula memateri keterangan-keterangan itu dengan alat-alat perekam suara sehingga dapat didengar, pencatatan dengan pita rekaman.

c. Mengelola yaitu:bermacam-macam kegiatan mengerjakan keterangan-keterangan dengan maksud menyajikannya dalam bentuk yang berguna.

d. Mengganda yaitu : kegiatan memperbanyak dengan berbagai cara dan alat sebanyak jumlah yang diperlukan.

e. Mengirim yaitu : kegiatan menyampaikan dengan berbagai cara dan alat dari satu 
pihak kepihak lain.

f. Menyimpan yaitu : kegitan menaruh dengan berbagai cara dan alat ditempat tertentu yang aman.

Berdasarkan dari pemahaman para ahli tersebut dapat di asumsikan bahwa administrasi perDinasan menjadi bagian yang sangat penting dalam menjalankan setiap pelaksanaan kerja sehingga tujuan yang sudah ditetapkan dapat terealisasi dengan baik. kelanjutan dari efektifitas administrasi yang berjalan dengan baik yaitu terpolanya perencanaan pada masa yang akan datang bagi instansi tersebut. demikian juga dengan pemerintahan desa yang menjalankan tugas-tugas pembangunan masyarakat harus mengacu pada suatu manajemen dalam administrasi agar adanya keseragaman dalam proses-proses perencanaa, pelaksanaan dan juga dalam tahapan pertanggunjawaban pada pemerintah berupa laporan penyelenggraan alokasi untuk pembangunan.

Berikutnya hasil wawancara dengan Sekretaris Dinas Pemberdayaan Masyarakat Dan Pemerintahan Desa Kabupaten Sintang dalam proses pelaksanaan pembinaan administrasi pemerintah kabupaten memberikan berbagai macam materi khususnya yang berkenaan dengan keuangan desa yaitu dengan pendampingan untuk program sitem keuangan desa yang sudah memnggunakan program komputer bagi setiap desa. Pembinaan umumnya untuk mencapai kesamaan pemahaman anatara pemerintah daerah karena adanya kebijakan terhadap sistem administrasi desa dan juga pemerintah desa sebagai pengguna ADD.

Berlandaskan pada hasil wawancara yang telah terhimpun dari Sekretaris Dinas Pemberdayaan Masyarakat Dan Pemerintahan Desa Kabupaten Sintang dapat di deskripsikan bahwa perubahan-perubahan yang terjadi dalam tataran kebijakan administrasi memerlukan sosialisasi kepada pemerintah desa. Melalui bimbingan teknis yang dilakukan secara serentak dengan mengundang kepala desa untuk ikut dalam kegiatan tersebut. Materi bimbingan umumnya mengacu pada kewajiban pemerintah desa yang telah ditetapkan dalam peraturan-peraturan yang sudah ada. Sedangkan untuk keuangan desa saat ini harus menggunakan suatu program khusus yang menggunakan media komputerisasi dan setiap desa harus memiliki nomor registrasi dalam rencana keuangannya. Sistem pelaporan juga harus menggunakan pedoman pelaporan yang harus di kerjakan sesuai dengan waktunya jika tidak maka akan berpengaruh pada anggaran dana desa tahun berikutnya.

Peningkatan kinerja kerja aparatur desa dalam hal administrasi tentunya belumlah maksimal walaupun setiap tahun sudah diadakan bimbingan teknis. Permasalahan yang sering terjadi bahwa tidak semua aparatur desa dapat mengikuti dan memahami berbagai sistem dan program karena keterbatasan akses-akses 
sehingga perbaikan sistem administrasi sering mengalami hambatan dan untuk itu Dinas PMPD selalu memberikan pendampingan bagi perbaikan administrasinya.

Hasil wawancara penelitian dengan Kepala

Bidang Kelembagaan Dinas Pemberdayaan Masyarakat Dan Pemerintahan Desa Kabupaten Sintang diperoleh informasi bahwa pelaksanaan bimbingan teknis dibagi menjadi dua yaitu untuk kepala desa dan Ketua BPD serta untuk aparatur desa pada bagian kelembagaan. sedangkan untuk bidang keungan dilakukan satu kali yaitu dengan mengundang bendahara desa dan juga kepala desa. Bimbingan teknis beisikan materi-materi tentang kebijakan pemerintah dalam administrasi dan juga pedoman pelaksanaan kegiatan kerja dan pembangunan di desa, dan juga pemberdayaan aset desa seperti BUMDes yang sudah disosialisasikan pada pemerintah desa.

Berikutnya hasil wawancara dengan KepalaBidangKelembagaanDinasPemberdayaan Masyarakat Dan Pemerintahan Desa Kabupaten Sintang sistem pelaksanaan bimbingan teknis selama tiga hari dan selanjutnya di lakukan rapat kerja atau raker dengan kepala desa sebagai tindak lanjut dari bimbingan teknis. Program penertiban sistem administrasi desa dikarenakan selama ini relatif banyak pemerintah desa belum dapat melaksanakan tujuan pembangunan secara efektif sedangkan dana yang dikeluarkan untuk tujuan pembangunan cukup besar.

Mengacu pada hasil wawancara dengan Kepala Bidang Kelembagaan Dinas Pemberdayaan Masyarakat Dan Pemerintahan Desa Kabupaten Sintang dapat dijelaskan bahwa secara teknis pelaksanaan bimbingan teknis bersifat berkelanjutan dimana sistem yang digunakan yaitu pelaksanaan bimbingan teknis dan kemudian dilanjutkan dengan rapat kerja dengan pemerintah desa dengan meminta kepada pemerintah desa untuk menyampaikan implementasi dari hasil bimbingan teknis tersebut. dalam hal ini pemerintah kabupaten juga membagikan panduan dan pedoman dalam bentuk buku dan sofcopy kepada kepala desa untuk dipelajari serta diimplementasikan dalam sistem administrasinya. Adapun kesalahankesalahan dalam implementasi sistem administrasi masih diberikan waktu untuk melakukan koordinasi dan konsultasi ke bagian kelembagaan Dinas PMPD kabupaten Sintang. Pelaksanaan pembinaan yang dilakukan secara terjadwal tersebut telah memiliki banyak kemajuan walaupun masih ada beberapa desa yang belum mampu untuk melaksanakan kebijakankebijak administrasi tersebut. Selain itu koordinasi pemerintah desa dengan pemerintah kecamatan dan kabupaten juga di arahkan agar dalam sistem administrasi selalu berada dalam koridor aturan dan untuk mewujudkan kinerja kearah tersebut tentunya memerlukan proses dan waktu bagi pemerintah desa. Jika melihat perubahan-perubahan dalam sistem administrasi pemerintahan sangat wajar pemerintah desa 
mengalami banyak kesulitan dan hambatan karena banyak faktor yang perlu diperhatikan terutama maslah akses-akses informasi yang belum semuanya terdapat di desa-desa.

\section{B. Koordinasi Dalam Pelaksanaan Pembinaan Administrasi}

Selanjutnya fungsi koordinasi menurut Siagian (2002 : 115) bahwa fungsi koordinasi dalam organisasi adalah untuk : “a) pencegahan konflik dan kontradiksi, b) pencegahan persaingan yang tidak sehat. c) pencegahan pemborosan.

d) pencegahan kekosongan ruang dan waktu dan, e) pencegahan terjadinya perbedaan pendekatan dan pelaaksanaan". Dari kelima peranan fungsi koordinasi tersebut maka dapat dilihat bahwa dengan adanya koordinasi akan memungkinkan pemanfaatan tenaga dan biaya menjadi lebih terarah dan efektif. Sedangkan menurut Nitisasmito (2000: 18) tentang manfaat dari adanya penyelenggaraan koordinasi dalam suatu organiasasi dikemukakan bahwa" dengan koordinasi tidak hanya dapat menghindari kesimpangsiuran, ketidaktepatan dan dobel pekerjaan, tetapi juga dapat dimungkinkan pekerjaan tersebut dapat diharapkan lebih efisien dan lebih efektif'.

Setelah mengetahui fungsi dan peran penting koordinasi dalam organisasi maka selanjutnya perlu dipahami yaitu metode dan teknik yang diselenggarakan untuk koordinasi, baik dalam ruanglingkup koordinasi intern maupun koordinasi ekstern. Dimana metode dan teknik koordinasi tersebut sangat menentukan bagi keberhasilan penyelenggaraan kegiatan koordinasi dalam setiap koordinasi. Untuk mengawali pemahaman tentang metode dan teknik koordinasi tersebut dapat dimulai dari syarat-sayarat yang diperlukan bagi penyelenggaraan koordinasi dalam suatu organisasi. Sejalan dengan itu menurut Tanzil ( 1991 : 219) bahwa persyaratan tersebut meliputi : pembagian tugas yang jelas dalam organisasi, semangat kerja yang besar diantara para karyawan (organisasi informal yang sehat dalam organisasi yang bersangkutan), Fasilitas kontak dan tata hubungan yang cukup bagi semua pihak dalam organisasi, diciptakan pada tahapantahapan permulaan dari sesuatu kegiatan dan dipertahankan sebagai proses yang kontinyu".

Berikutnya hasil wawancara dengan Sekretaris Dinas Pemberdayaan Masyarakat Dan Pemerintahan Desa Kabupaten Sintang diperoleh informasi bahwa tujuan dari koordinasi antar instansi dalam pelaksanaan pembinaan pada pemerintah desa karena hubungan pemerintah desa dalam sistem pemerintahan dan keuangannya. Selain itu koordinasi tersebut meminta kepada pihak-pihak instansi tersebut untuk dapat memberikan materi-materi pada saat pelaksanaan kegiatan Bimtek dilakukan. Pelaksanaan Bimtek bagi aparatur desa sifatnya menyeluruh walaupun sudah ada desa-desa yang sudah baik sistem administrasi tetap wajib 
mengikuti. Sebagai prasyarat dalam mencairkan keuangan Bimtek bagi aparatur desa diharapkan dapat meningkatkan kinerja kerjanya yang semakin hari sistem pelaksanaan pemerintahan semakin kompleks dan sistem administrasi menjadi aspek utama dalam pertanggungjawaban administrasi kegiatan pemabngunan di desa.

Selanjutnya hasil wawancara dengan Sekretaris Dinas Pemberdayaan Masyarakat Dan Pemerintahan Desa Kabupaten Sintang melalui koordinasi dan komunikasi setiap kegiatan pelaksanaan kegiatam pembinaan dan rapat kerja dengan pemerintahan desa selalu berjalan dengan lancar. Pembinaan yang berkelanjutan juga tidak hanya terbatas pada saat kegiatan Bimtek dan juga Rapat Kerja akan tetapi koordinasi Dinas Pemberdayaan dan Pemerintahan Desa dengan pemerintahan desa terus dilakukan melalui pelayanan di Dinas setiap harinya. Pola koordinasi demikian juga dapat melalui mediamedia komunikasi selurler untuk mempermudah pemerintah desa dalam menyampaikan kendalakendala yang dihadapi dalam penyampaian administrasi pelaporan kegiatan pemerintah desa.

Mengacu pada hasil wawancara dengan dengan Sekretaris Dinas Pemberdayaan Masyarakat Dan Pemerintahan Desa Kabupaten Sintang yang telah terhimpun dapat di deskripsikan bahwa pola koordinasi tidak hanya dalam pelaksanaan kegiatan bimbingan teknis akan tetapi juga dalam hal pelayanan di Dinas PMPD sehari-hari. Pelayanan pada pemerintahan desa dilakukan untuk menyelaraskan hasil-hasil bimbingan dan juga mengurangi kendalakendala yang dihadapi pemerintaahan desa. Dalam konteks koordinasi langsung yang sifatnya perjalanan dinas dari Dinas PMPD kabupaten sintang juga dilakukan sebagai upaya pendampingan kepada pemerintahan desa dalam pengelolaan administrasinya.

Sasaran peningkatan kapasitas dan kinerja pemerintahan desa melalui pembinaan menunjukan adanya perubahan yang semakin baik dan terarah. Demikian juga dengan sistem administrasi pada lembaga BPD yang dapat kooperatif dengan pemerintahan desa karena sistem administrasi merupakan tanggungjawab bersama antara kepala desa dan juga BPD. Penilaian terhadap pengelolaan administrasi dilakukan oleh instansi yang berkaitan dengan pelaksanaan program kerja kepala desa BPD dan dalam hal ini kelanjutannya untuk memberikan kelancaran dalam berbagai perencanaan anggaran dana desa berikutnya.

Hasil wawancara dengan Kepala Bidang Kelembagaan Dinas Pemberdayaan Masyarakat Dan Pemerintahan Desa Kabupaten Sintang menyampaikan bahwa tanpa berkoordinasi dengan instansi lainnya akan sangat sulit untuk mencapai tujuan tertib administrasi. Kesulitan tersebut di karenakan dalam sistem administrasi desa terdapat bebrapa aspek yang sangat krusial yaitu sistem pelaporan kegiatan yang bersifat administrasi, sistem penggunaan keuangan dan 
juga poelaksanaan kegiatan yang riil dilapangan.

Lebih lanjut menurut hasil wawancara

KepalaBidangKelembagaanDinasPemberdayaan Masyarakat Dan Pemerintahan Desa Kabupaten Sintang bahwa dalam satu tahun setiap aparatur desa dan BPD wajib menyampaikan kinerja kerja melalui pelaporan yang sudah ada format pelaoprannya. Selain itu bukti-bukti autentik yang diperunakan dalam pelaksanaan tugas dan kegiatan harus dilampirkan yang asli. Melalui pembinaan khususnya secara bimbingan teknis

(Bimtek) tentunya aparatur desa paling tidak memiliki panduan dan pedoman serta mengetahui dampaknya jika tidak mengikuti tata administrasi yang sudah ditentukan tersebut. Selanjutnya untuk mengetahui lebih jauh implementasi terhadap tertib administrasi desa bidang kelembagaan mengundang seluruh aparatur desa dan BPD desa.

Dalam rapat kerja tahunan yang materinya untuk mengetahui perkembangan administrasi dari desa yang telah dilakukan dan telah dilaksanakan jika masih belum pada saat itulah diperbaiki dan diarahkan menjadi lebih baik.

Berdasarkan pada hasil wawancara yang telah terhimpun dari Kepala Bidang Kelembagaan Dinas Pemberdayaan Masyarakat Dan Pemerintahan Desa Kabupaten Sintang dapat de deskripsikan bahwa pembinaan yang dilakukan selama ini melalui kegiatan bimbingan teknis telah menunjukan adanya perubahan bagi pelaksanaan administrasi pemerintahan desa. Pelaksanaan terus dilaksanankan setiap tahunnya untuk mematikan agar tertib administrasi desa tidak menjadi hambatan bagi pelaksanaan pembangunan di desa yang dapat merugikan masyarakat desa. Prinsip yang ditanamkan dalam pembinaan yaitu harus sungguh-sungguh menjadi aparatur desa yang dapat menggunakan biaya ADD secara efisien. Peningkatan kinerja kerja aparatur desa saat ini juga sudah menjadi keharusan dalam sistem pemerintahan karena desa sudah menggunakan prinsip otonomi dalamkeuangannya.

Aparatur desa di dalam koordinasi setiap tahunnya untuk kegiatan diwajibkan untuk mengalokasikan dana kegiatan peningkatan aparatur desa agar dalam penyampaian laporan dan kinerja dapat terlihat perubahan apsaja yang telah dilakukan selama mengikuti kegiatan tersebut. Untuk pelaksanaan koordinasi seluruh staf dan juga PNS yang ada pada bidang kelembagaan dilibatkan karena jumlah aparatur desa yang sertakan setiap kali bimtek paling sedikit dua orang. Adapun koordinasi juga tidak hanya sebatas pada kegiatan tersebut akan tetapi koordinasi terus dilakukan setiap tiga bulan yang dilakukan melalui pemberitahuan surat kepada pemerintah desa untuk menyampaikan hasil implementasi dari kegiatan Bimtek tersebut. yang umumnya menjadi kesulitan dalam koordinasi yaitu tidak semua desa saat ini sudah dapat menerima akses-akses telekomunikasi dari Bidang Kelembagaan Dinas Pemberdayaan dan Pemerintahan Desa. 
Berdasarkan hasil wawancara dengan Kepala Desa di Kabupaten Sintang yang ditemui pada saat penelitian berlangsung diperoleh informasi diakuinya bahwa peran Bidang kelembagaan di Dinas Pemberdayaan dan Pemerintahan desa Kabupaten Sintang sangat membantu dalam menciptakan tertib administrasi desa. tertib administrasi desa saat ini menjadi pilar utama dalam penilaian kinerja kerja kepala desa dan pemerintahan desa. Koordinasi oleh Dinas PMPD ke pemerintah desa selain melalui pelaksanaan Bimtek juga ada dialokasikan untuk rapat kerja sesuai jadwal yang telah di tetapkan.

Selanjutnya hasil wawancara dengan salah seorang dari beberapa Kepala Desa di Kabupaten Sintang yang ditemui pada saat penelitian berlangsung mengatakan bahwa pelaksanaan koordinasi dalam konteks tertib administrasi harus dilakukan secara sinergis baik oleh pemerintah desa dan juga dari instansi yang berwenang. Dalam mewujudkan tertib administrasi tersebut diakuinya sangat sulit karena harus sungguh-sungguh mengikuti segala aturan tentang administrasi yang ada. Dalam konteks itulah maka pemerintah desa sangat perlu koopratif dalam koordinasi dengan Bidang kelembagaan yang dapat memberikan informasi bagi pemerintah desa.

\section{Metode Penelitian}

Sedangkanpenelitianinijenisnyapenelitian deskriptif, yakni penelitian yang dimaksudkan untuk membuat gambaran atau mengambarkan keadaan ataupun kejadian. Penelitian deskriptif menurut Nawawi (1993:63) adalah dapat diartikan "Sebagai prosedur pemecahan masalah yang diselidik dengan menggambarkan/ melukiskan keadaan subyek/obyek penelitian (seseorang, lembaga, masyarakat dan lain-lain) pada saat sekarang berdasarkan fakta-fakta yang tampak atau sebagaimana adanya". Sehubungan dengan hal ini yakni berkenaan dengan Upaya Pembinaan Aparatur Desa Oleh Dinas Pemberdayaan Masyarakat Dan Pemerintahan Desa Kabupaten Sintang.

Subjek penelitian merupakan sesuatu yang akan diteliti, Menurut Faisal (2005:109): "subjek penelitian adalah menunjuk pada orang/individu atau kelompok yang dijadikan unit atau satuan (Kasus) yang diteliti”. Adapun yang menjadi subjek penelitian adalah sebagai berikut :

1. Kepala Dinas Pemberdayaan Masyarakat Dan Pemerintahan Desa Kabupaten Sintang

2. Sekretaris Dinas Pemberdayaan Masyarakat Dan Pemerintahan Desa Kabupaten Sintang

3. Kepala Bidang Kelembagaan Dinas Pemberdayaan Masyarakat Dan Pemerintahan Desa Kabupaten Sintang

4. Kepala Desa di Kabupaten Sintang yang ditentukan dengan menggunakan teknik Insidental Sampling

Untuk suatu karya ilmiah yang baik dan dapat memperoleh hasil yang baik pula hendaknya data-data haruslah lengkap dan jelas 
pula, pengumpulan data merupakan pengadaan data untuk suatu penelitian. Menurut Nasir (1988:211) "pengumpulan data adalah prosedur yang sistematik dan standar untuk memperoleh data yang diperlukan”. Dengan demikian penelitian harus menggunakan teknik-teknik tertentu dalam pengumpulan data, oleh karena itu dalam penelitian ini digunakan tehnik-tehnik sebagai berikut :

1. Pengamatan/Observasi: yaitu mengadakan pengamatan secara langsung pada objek-objek dan mencatat hal-hal yang berkaitan dengan masalah Upaya Pembinaan tertib Administrasi Desa Oleh Dinas Pemberdayaan Masyarakat Dan Pemerintahan Desa Kabupaten Sintang.

2. Wawancara atau interview adalah wawancara subjek penelitian yang berhubungan dengan permasalahan yang menjadi objek dalam penelitian ini yakni Upaya Pembinaan tertib Administrasi Desa Oleh Dinas Pemberdayaan Masyarakat Dan Pemerintahan Desa Kabupaten Sintang.

3. Studi Dokumentasi, yaitu mempelajari dan menggali data skunder yang diperlukan dalam menunjang penelitian ini seperti tentang gambaran tentang Upaya Pembinaan tertib Administrasi Desa Oleh Dinas Pemberdayaan Masyarakat Dan Pemerintahan Desa Kabupaten Sintang, disamping itu juga studi dokumentasi dilakukan untuk mandapatkan berbagai macan dokumen berupa buku-buku, laporan teknis yang berkaitan dengan penelitian.

\section{Simpulan}

Pelaksanaan Pembinaan Administrasi melalui pelaksanaan Bimbingan Teknis (Bimtek) yaitu Bimtek administrasi pemerintahan, keuangan desa, dan pengelolaan aset desa bagi Aparatur Desa dan Badan Permusyawaratan Desa (BPD), pelaksanaan rapat kerja dengan kepala urusan di desa, serta pemantauan dan konsultasi laporan tahunan kepala desa.

Koordinasi Dalam Pelaksanaan Pembinaan Administrasi dilakukan secara internal oleh kepala bidang yang ada di Badan Pemberdayaan dan Pemerintahan desa, dengan Kepala Dinas dan juga Sekretaris Badan. secara internal koordinasi dilakukan dengan instansi lainnya seperti Sekretariat daerah yaitu Tata Pemerintahan, Bagian Hukum sekda, Dinas Keuangan dan pendapatan daerah serta dengan Inspektorat Kabupaten.

\section{Daftar Pustaka}

Arikunto,

Suharsimi.

(2007).

ManajemenPenelitian. Jakarta : Rineka Cipta

Bratakusuma, Dedi Supriadi. (2001). Otonomi Penyelenggaraan Pemerintah Daerah. Jakarta Pustaka Pelajar.

Faisal,S. (2005). Format-Fornat Penelitian Sosial. Jakarta : PT. Raja Grafindo persada. Gie, The Liang. (2002). Ensiklopedi Administrasi. Jakarta : Gunung Agung.

Handayaningrat, S. (1991). Administrasi 
66 Perahu, Volume 8 Nomor 1, Maret 2020, Hlm 56-66

Pemerintahan Dalam Pembangunan

Nasional. Jakarta : Haji Masagung.

Nasir, M. 2003. Metode Penelitian Jakarta :

Ghalia

Nawawi. (1993). Metodologi Penelitian

Kualitatif. Yogyakarta: Graha Ilmu.

Nitisasmito (2000). Manajemen Suatu Dasar Dan

Pengantar. Jakarta : Ghalia Indonesia.

Siagian, Sondang P. (2002). Administrasi

Pembangunan (konsep, dimensi dan

strateginya). Jakarta : Bumi Aksara.

Sutarto (1998). Pengantar Ilmu Administrasi Dan

Manajemen. Yogyakarta : Gajah Mada

University Press.

\section{Undang-Undang dan Peraturan}

Undang-Undang Nomor 6 tahun 2014 Tentang

Desa.

Peraturan Bupati Sintang Nomor 50 Tahun 2008

Tentang Susunan Organisasi Dan Tata

Kerja Dinas Pemberdayaan Masyarakat

dan Pemerintahan Desa Kabupaten

Sintang.

Peraturan Daerah Kabupaten Sintang Nomor 13

Tahun 2006 Tentang pedoman Penyusunan

Organisasi dan Tata Kerja Pemerintah

Desa 
